I contend, allows literature to play a crucial role in society and fuels a love of literature that motivates lifelong reading. Our critique of texts has advanced our understanding of how texts work, but we need also to allow texts to work on us.

Cristina V. Bruns

University of California, Santa Barbara

\section{Milton and Religious Violence}

\section{To THE Editor:}

In its finest moments, Feisal G. Mohamed's "Confronting Religious Violence: Milton's Samson Agonistes" (120 [2005]: 327-40) presses toward the realization that, in the tragedy, Milton "frustrates uncomplicated narrativization of the Western tradition," as well as "an uncomplicated vision of cultural history" (337). Indeed, much recent criticism of Samson Agonistes drives toward these propositions, each of which finds striking reinforcement in the program notes by Robert Scanlan to the April 2003 performance reading of Milton's tragedy at New York City's 92nd Street Y. According to Scanlan:

Samson Agonistes is a troubling work at any time, for it is a timeless study of the self-righteous instinct urging all defeated men to vengeance and violence. As such, it is a work which remains curiously open, for who can without confounding ambivalence be sure who this English Samson is meant to stand for, or who next might feel justified in invoking his example.

Indisputably, Milton at one time embraced what Mohamed calls "religious extremism and political radicalism" (337). The question is whether Milton ever cast a dubious eye on such commitments, much as Cromwell eventually did; and the answer to that question seems forthcoming in $A$ Treatise of Civil Power where Milton writes that "no man can know at all times" if "divine illumination ... be in himself" (Complete Prose Works of John Milton, ed. Robert W. Ayers, vol. 7 [New Haven: Yale UP, 1980] 242); then in Paradise Lost where he frets over those "feigning ... to act / By spiritual [power], to themselves appropriating / The spirit of God" (12.517-19); and finally in his 1671 poetic volume where, in their pairing, Paradise Regained may be said to place an ideological check on Sam- son Agonistes. The crucial question is whether Milton's is a mind fixed or changing.

Mohamed has made much of his disagreements with John Carey and of Carey's disagreements with Stanley Fish. Yet at their core, both Carey's Milton and Fish's are "subtle-minded" poets with Milton's subtleties of mind marked most strikingly by various transgressions of his scriptural sourcebook. With Milton, the matter is always more complicated than routing a poem through this or that tradition. At issue, most of the time, is Milton and which traditions? In which of their manifestations? Carey is on target when he reminds us that Samson Agonistes is a remarkable rewriting of the Judges narrative, one omitting Samson's prayer and thus questioning Samson's motivation. Milton's transgressive maneuvers are given their point when we remember that Samson was the hero, as well as patron saint, of the New Model Army and that the first lines of its prayer book heroized Samson as a soldier at prayer. To equivocate on Samson's prayer, as Milton does ("as one who pray'd, / Or some great matter in his mind revolv'd" [1637-38; my italics]), is to equivocate on Samson's heroism. By altering the Judges story yet again, Milton leaves in doubt whether God's agency has now returned to Samson, this time by modifying the scriptural account to allow for escape of " $[t]$ he vulgar ... who stood without" (1659). While the spirit of the Lord may have left Samson, evidently it has not yet left history. Not a retaliatory but a merciful God enters history and transforms it. In Samson Agonistes, then, what is spared is owing not to Milton's Samson but to Milton's God, who here exemplifies not retributive but distributive justice.

Milton does not sanitize the scene of destruction, removing what Mohamed calls "grisliness" from it (335). On the contrary, he writes such signatures of violence into his poem: "Blood, death, and deathful deeds .../ Ruin, destruction at the utmost point" (1513-14); then depicts "thunder [bursting] / Upon the heads of all who sate beneath" (1651-52); and thereupon presents Samson as "[s]oak't in his enemies blood" and caked with "clotted gore" $(1726,1728)$. The thunder-bursting "hero" of Samson Agonistes stands in startling contrast to the Son of Paradise Lost, who, "half his strength" withholding, "check'd / His Thunder in 
mid-Volie" in order "Not to destroy" (6.853-55), this contrast suggesting that Milton's tragedy is less an exaltation of a hero than the problematizing of a then received notion of heroism. The ultimate question is whether Milton's tragedy, as a cherished artifact of Western literary tradition, shows, in Mohamed's words, "evidence of the very brand of thought that the political dominant vilifies in the Other" (338) or whether, breaking free of his own culture of violence, Milton here mounts a critique of it. When it comes to answering that question, Mohamed writes cunningly; Carey, compellingly.

Joseph Wittreich Graduate Center, City University of New York

\section{To THE EDITOR:}

We can only be grateful for Feisal G. Mohamed's "Confronting Religious Violence: Milton's Samson Agonistes," an insightful essay that brings the past and the present into a genuinely productive dialogue. Yet as much as I found myself instructed and delighted by Mohamed's analysis, I respectfully disagree with him on two key points.

Mohamed argues that we can detect Milton's approval of Samson's bringing the roof down through the lack of graphic detail. Mohamed writes:

The Miltonic Messenger's very brief statement on the human cost of Samson's actions, by comparison [with Senecan tragedy], seems designed not to grant the Philistines the status of human beings. Unlike the Chorus's more graphic description of miraculous "slaughter," which description incorrectly discerns God's ways, the Messenger's account glosses over human torment in a way that does allow comfortable attribution of the action to divine agency:

The whole roof after them with burst of thunder

Upon the heads of all who sat beneath, Lords, Ladies, Captains, Counsellors, or Priests

Thir choice nobility and flower, not only

Of this but each Philistian City round...

(1651-55)

We are never allowed to forget in these lines the victims' status as Philistine political elite and the attendant association of this class with oppression of Israel. The kind of human suffering that elicits our horror over Hercules's actions and complicates our response to Pentheus's hubris simply does not emerge in Milton's portrait of the Philistine massacre.

Consequently, Mohamed concludes, we can see in Samson Agonistes an example of what Fredric Jameson calls "ideological closure" (336).

While Milton does not give us the precise details of what brick bashed in whose head, nor does he describe the resulting splatter pattern, Milton does not gloss over the suffering of the Philistines, as evidenced by the lines immediately preceding the passage quoted by Mohamed. In this passage, Manoa tells us that the Philistines are not united on Samson's fate. When he approaches various Philistine lords on the matter of ransoming Samson, Manoa recounts:

Some much averse I found and wondrous harsh, Contemptuous, proud, set on revenge and spite Others more moderate seeming, but thir aim

Private reward

(1461-64)

But a not insignificant minority-one-third, to be precise-Manoa finds

More generous far and civil, who confess'd They had anough reveng'd, having reduc't Thir foe to misery beneath thir fears,

The rest was magnanimity to remit. (1467-70)

It is at this point, immediately after the reader discovers that mercy exists among the Philistines, that we first hear of everyone's destruction: "What noise or shout was that?" Manoa suddenly asks, "it tore the Skie" (1472). Imagining a cry so agonized that "it tore the Skie" highlights rather than glosses over the torment of the Philistines as the building collapses on their heads. And we may speculate that Milton's blindness would have made sound all the more acute for the poet.

Furthermore, given that some, if not all, of the "[m]ore generous far and civil" are in all likelihood also caught up in the slaughter, one has to ask if they deserved the same fate as their less merciful tribesmen. In other words, the sheer lack of distinction invites the reader to ask if everyone in the theater was equally guilty. Are the generous and civil Philistines, who have had "anough" revenge, as worthy of death as those who continue to desire Samson's humiliation? Does the simple 